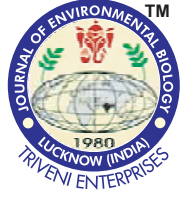

(3)

\title{
Energy input-output relationship of soybean-based cropping systems under different nutrient supply options
}

Authors Info

K. Prajapat ${ }^{1 *}$, A.K. Vyas ${ }^{2}$, S. Dhar ${ }^{3}$, N.K. Jain ${ }^{2}$, Mohd. Hashim ${ }^{4}$ and G.L. Choudhary ${ }^{5}$

${ }^{1}$ ICAR-Indian Institute of Wheat and Barley Research,

Karnal-132 001, India

${ }^{2}$ Indian Council of Agricultural

Research, New Delhi-110 012, India

${ }^{3}$ ICAR-Indian Agricultural Research Institute, New Delhi-110 012, India

${ }^{4}$ ICAR-Indian Agricultural Research Institute, RS-Pusa-848 112, India

${ }^{5}$ Bihar Agricultural University,

Sabour-813 210, India

${ }^{*}$ Corresponding Author Email kp.agron@gmail.com

Key words

Cropping systems

Carbon balance

Carbon flux

Energy use efficiency

Nutrient supply options

Publication Info

Paper received : 06.09.2016

Revised received : 10.05.2017

Re-revised received : 18.05.2017

Accepted : 24.06.2017

\begin{abstract}
Aim : Increase in agricultural productivity with minimal energy utilization without any adverse impact on the environment is a pre-requisite of present agricultural practices through best agronomic management of crop production. The present investigation aimed to identify the most energy efficient cropping system and nutrient supply option which exert minimal impact on the environment.
\end{abstract}

Methodology : The experiment was carried out for two consecutive years at Indian Agricultural Research Institute, New Delhi for the evaluation of soybean-based cropping systems with five nutrient supply options with respect to energy parameters, as well as carbon emission equivalents. The different inputs used in raising the crops and output of crops were converted into energy and carbon equivalents using standard conversion factors and used for computation of different energy and carbon efficiency indices.

Results : The soybean-potato-mungbean system recorded significantly highest system productivity in terms of soybean seed-equivalent yield $\left(7.68 \mathrm{th}^{-1}\right)$, however soybean-chickpea-fodder sorghum system recorded highest net energy $\left(333.9 \times 10^{3} \mathrm{MJ} \mathrm{ha}^{-1}\right)$, energy efficiency (9.56), energy productivity $\left(179 \mathrm{gMJ}^{-1}\right)$, energy profitability (8.6 MJ ha'), human energy profitability (105.2) and energy intensiveness (6.76). Soybean-chickpea-fodder sorghum system maintained higher carbon output and carbon efficiency which was 22.9 and $15.6 \%$ higher over soybean-wheat system, respectively. Among the nutrient supply options, application of 50\% RDF + 50\% RDN through FYM accounted for the highest energy output (286.1 MJ ha ${ }^{-1}$ ), net energy (240.3 MJ ha" $)$ and energy output efficiency ( $\left.968 \mathrm{MJ} \mathrm{ha}^{-1} \mathrm{day}^{-1}\right)$ and also reduced the carbon flux to the atmosphere as compared to $100 \%$ RDF.

Interpretation : The cropping system followed and sources of nutrient supply had considerable impact on utilization of energy, as well as carbon emission equivalents. Therefore, besides looking only upon productivity of a particular cropping system and management level, their relative energy efficiency and resultant impact on the environment should also be taken into consideration for ensuring judicious use of nonrenewable resources.
Management Goal

I.

Selection of most energy efficient and lower carbon emission cropping system and nutrient combination

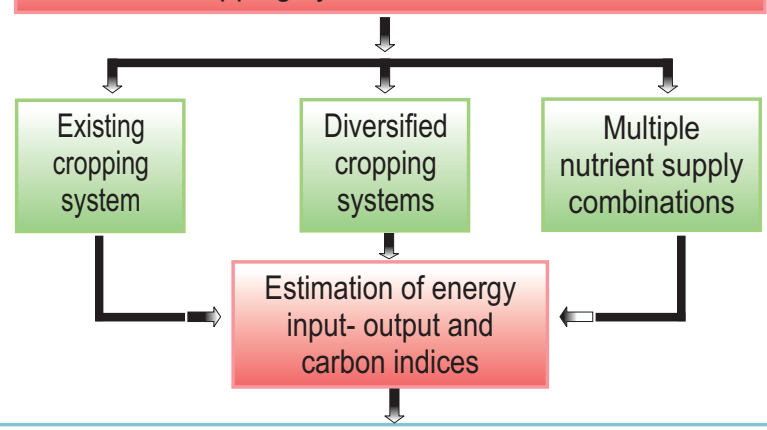

Most energy efficient crop sequence with optimized nutrient supply which exert minimum impact on the environment 


\section{Introduction}

In the modern agriculture, increasing energy use efficiency and reducing carbon footprint of crop production are the two most important sustainability issues (Singh et al., 2016). Energy is the most valuable input in agricultural production, which is used in various forms such as mechanical (farm machines, human labour, animal draft), chemical (fertilizer, pesticides, herbicides) and electrical (Singh and Ahlawat, 2015). Judicious use of these inputs is required to increase agricultural productivity without adversely affecting the environment. Crop yields and food supply to the consumers are directly linked to energy, which means sufficient energy is needed in the right form at right time for adequate crop production (Negi et al., 2016). The rising cost of energy has emphasized to conserve the energy particularly in India which is facing energy crisis caused by fuel shortage and high prices of diesel. The tillage and fertilizer management are the major contributors in energy consumption in any of the agricultural production systems, which are solely dependent on non-renewable energy sources (Billore et al., 2009). The nonrenewable energy is expensive and liable to exhaust innear future. The steady decline in the energy-use efficiency in the present agriculture is a matter of great concern. Increasing intensity of irrigation and fertilizers for higher productivity also increasing the energy consumption in crop production but at the same time decreasing the energy use efficiency (Sharma and Thakur,1989; Mandal et al., 2002).The rapid increase in productivity with intensive use of non-renewable energy sources has very short-term advantages and must have balance with long term cost to the society as whole for depleting the resources (Franzluebbers and Francis,1995). The increasing intensity in cropping system also led to consumption of more energy, though it depends on the nature of crops in the system. Inclusion of legumes in the system reduces the energy inputs to a great extant as these crops require very less energy in production. Soybean-wheat system has been reported to be the most energy input system, whereas, soybean-chickpea was most energy productive and intensiveness in central part of India (Billore et al., 2009). The conservation tillage (Cavalaries and Gemtos, 2004) and adoption of integrated approach for nutrient management offer most potential measures to minimize the dependency on non-renewable energy leading to increased share of renewable energy, which will pave the way for sustainability. Integration of organic manures with chemical fertilizers increase the energy productivity of soybean-based cropping systems, while reversed with chemical fertilizers alone (Billore et al., 2005).

Increased mechanization and intensification of agriculture has increased the utilization of fossil fuel, has greater impact on the global carbon and nitrogen cycles, possibly leading to the global temperature increase (Lal, 2004). Efficient management practices are need to be identified which mitigate GHGs emissions to lower the carbon footprints of crop production activities (Gan et al., 2011) as sustainability of crop production partly depends not solely on higher productivity on long run, but also depends on its carbon footprint to environment (Dubey and Lal, 2009). Adopting improved agronomic practices such as using high yielding crop varieties, timely control of crop diseases, efficient crop rotations with crops which allocate more carbon below ground and judicious nutrient management can reduce the green house gas emission from crop production through sequestration of carbon in the soil (Smith et al., 2008; Malmuti et al., 2009; Khosa et al., 2010; Oo et al., 2016). Integration of renewable sources of nutrients such as organic manures and biofertilizers can reduce the external supply of nutrients through chemical fertilizers and also increases the soil carbon pool and reduces the carbon flux out of the soil system.

Therefore, recommendation of a cropping system for particular region, only per unit crop productivity and profitability should not be taken into consideration. The system should also be assessed in terms of energy consumption and impact on environment. Information on bio-energy output-input relationship and environment impact has rarely been quantified and analyzed in most of the cropping system followed. The present paper was carried out to analyze the energy budgeting and carbon footprints under different soybean-based cropping systems with various nutrient supply options.

\section{Materials and Methods}

Site description and climate : The experiment was conducted for two consecutive years during rainy (July-October), winter (November-March) and summer (April-June) seasons of 2011-12 and 2012-13 at the research farm of Indian Agricultural Research Institute (IARI), New Delhi. The mean annual rainfall of Delhi is $650 \mathrm{~mm}$ and more than $80 \%$ generally occurs during the southwest monsoon season (July-September) with mean annual evaporation of $850 \mathrm{~mm}$. The total rainfall received during JulyOctober, November-March and April-June was 434, 34, 21 and 482, 164, $162 \mathrm{~mm}$ during 2011-12 and 2012-13, respectively. The top $15 \mathrm{~cm}$ soil of the experimental field had $157 \mathrm{~kg} \mathrm{ha}^{-1}$ alkaline permanganate oxidizable $\mathrm{N}, 14.2 \mathrm{~kg} \mathrm{ha}^{-1}$ available $\mathrm{P}, 240 \mathrm{~kg} \mathrm{ha}^{-1}$ $1 \mathrm{~N}$ ammonium acetate exchangeable $\mathrm{K}$ and $3.8 \mathrm{~g} \mathrm{~kg}^{-1}$ organic carbon with $7.9 \mathrm{pH}$ and $0.34 \mathrm{dSm}^{-1} \mathrm{EC}$.

Layout and treatments : The experiment was laid out in a stripplot design with three replications. The vertical strip consisted of four cropping systems, soybean (Glycine max (L.) Merrill)-wheat (Triticum aestivum L.), soybean-wheat-mungbean (Vigna radiata (L.) Wilczek), soybean-chickpea (Cicer arietinum L.)-fodder sorghum (Sorghum bicolor (L.) Moench) and soybean-potato (Solanum tuberosum L.), while the horizontal strips consisted of five nutrient supply options (control, $100 \%$ recommended dose of fertilizers (RDF), $50 \%$ RDF $+50 \%$ recommended N(RDN) through farm yard manure (FYM), 50\% RDF + 25\% RDN through $\mathrm{FYM}+$ biofertilizers and 25\% RDF + 50\% RDN through FYM + 
biofertilizers]. The RDF (N, $\mathrm{P}_{2} \mathrm{O}_{5}$ and $\left.\mathrm{K}_{2} \mathrm{O}\right)$ for soybean, wheat, chickpea and mungbean was calculated through soil test crop response (STCR) equations for the experimental farm (Sharma and Singh, 2007) and by taking initial soil test values of available $\mathrm{N}, \mathrm{P}$ and $\mathrm{K}$ at the beginning of the experiment and targeted yields of crops as 2.0, 5.0, 2.0 and $1.0 t_{\text {ha }}{ }^{-1}$, respectively. The dose of RDF for potato and fodder sorghum was used as per general recommendations because STCR equations were not available for these crops. The recommended dose of fertilizers ( $\mathrm{N}: \mathrm{P}_{2} \mathrm{O}_{5}: \mathrm{K}_{2} \mathrm{O} \mathrm{kg} \mathrm{ha}{ }^{-1}$ ) under $100 \%$ RDF were 50:75:26 (soybean), 158:76:47 (wheat), 150:60:80 (potato), 44:27:3 (chickpea), 25:30:0 (mungbean) and 120:60:40 (fodder sorghum). The sources of fertilizer were urea for $\mathrm{N}$ (after adjusting the quantity of $\mathrm{N}$ given by di-ammonium phosphate), di-ammonium phosphate for $\mathrm{N}$ and $\mathrm{P}$ and muriate of potash for $\mathrm{K}$. In soybean, chickpea and mungbean, all quantity of fertilizers was applied at the time of sowing. For wheat one third and for potato and fodder sorghum half of $\mathrm{N}$ and full dose of $\mathrm{P}$ and $\mathrm{K}$ were applied as basal. Remaining $\mathrm{N}$ was given in two equal splits, after first irrigation and at tillering stage in wheat, whereas in potato and fodder sorghum remaining $\mathrm{N}$ was applied at 45 and at 30 days after sowing/planting, respectively. The FYM was applied before sowing of crops based on the nitrogen equivalent basis and requirement of each crop in respective plots. The average nutrients composition of FYM was $0.58,0.28$ and $0.53 \%$ of N,P and $\mathrm{K}$, respectively. Seeds/tubers of crops were treated with Rhizobium/Azotobacter and PSB in respective treatments at the time of sowing.

The experiment was initiated with soybean crop in rainy season (July-October) in 2011. During winter season, wheat, chickpea and potato were grown after soybean harvest. Mungbean and fodder sorghum were grown in summer after harvest of winter season crops in respective cropping systems. The system productivity of all the cropping system was computed by converting economic yield of all the crops into soybean seedequivalent yield (SSEY), based on the prevailing market/minimum support price during each year.

Energetics : The inputs and outputs of different crops were converted in terms of energy input and output using energy equivalents and used for calculation of different energy parameters as suggested by Singh and Mittal (1992).

Carbon budgeting : The inputs used and field operations adopted in raising the crops were converted into carbon input equivalent per hectare $\left(\mathrm{C}_{\mathrm{e}}\right.$ ha $\left.^{-1}\right)$ using the carbon emission equivalents (West and Marlend, 2002) and carbon output was calculated by multiplying the total biomass output of the crops with 0.44 as the plant biomass contains an average $44 \%$ carbon (Lal, 2004). The carbon input and output so obtained were used to calculate carbon efficiency and carbon footprint $\left(\mathrm{kg} \mathrm{C}_{\mathrm{e}} \mathrm{kg}^{-1}\right.$ SSEY).
Net carbon flux in soil : The net carbon flux $\left(\mathrm{kg} \mathrm{C}_{\mathrm{e}}\right.$ ha $\left.{ }^{-1} / \mathrm{year}\right)$ is the difference between carbon sequestered in the soil and total carbon emission from all inputs and fuel/energy consumption from farm operations (West and Marland, 2002).

Statistical analysis : Data obtained from the experiment were statistically analyzed using F-test (Gomez and Gomez, 1984). LSD values at $P=0.05$ were used to determine the significance of difference between the treatment means.

\section{Results and Discussion}

Mean yield of soybean, wheat and mungbean did not differ significantly under different cropping systems (Table 1). Significantly highest yield of soybean was recorded with the nutrient supply combination, where FYM and biofertilizers were added with lower levels of RDF (25\% RDF + 50\% RDN through FYM + Rhizobium and PSB). The lower level of RDF (25\% RDF) under above treatment had low levels of fertilizer nitrogen which augmented nodulation in crop (Prajapat et al., 2015), might have resulted in higher biological nitrogen fixation and solubilization of more amount of phophorus by PSB, which was further enhanced by addition of organic manure and ultimately increased the growth and yield. Wheat grain and potato tuber yields were significantly higher under the nutrient supply of $100 \%$ RDF, being statistically at par with 50\% RDF +50\% RDN-FYM. Wheat and potato crops require quick supply of nutrients and had better growth with readily available source of nutrients, therefore had better yield with RDF. The results are in conformity with the findings of Behera et al. (2007) in wheat and Kumar et al. (2009) in potato. Whereas, significantly maximum chickpea seed yield was obtained in 50\% RDF + 50\% RDN treatment through FYM, followed by $100 \%$ RDF. As FYM and biofertilizers releases nutrients slowly meets the requirement of slow growing chickpea during winter season and increases the yield (Ramesh et al., 2009).The above treatment also recorded significantly highest mungbean seed and sorghum green fodder yields.

System productivity in terms of soybean seed-equivalent yield (SSEY) indicated that soybean-potato-mungbean system registered significantly higher SSEY (7.68 tha $\left.\mathrm{t}^{-1}\right)$, followed by soybean-chickpea-fodder sorghum (6.92 $\left.\mathrm{t} \mathrm{ha}^{-1}\right)$ (Table 1). Further, SSEY was significantly highest $\left(6.79 \mathrm{t} \mathrm{ha}^{-1}\right)$ with nutrient supply combination of $50 \%$ RDF $+50 \%$ RDN through FYM.

The energy input/consumption under different inputs and nutrient supply options of crops was computed mean over two years (Table 2). Out of total energy input, irrigation accounted for bulk of energy input in soybean $(39.2 \%)$, wheat $(42.9 \%)$, mungbean $(49.8 \%)$ and fodder sorghum (41.6\%). Seed requirement accounted for more than half of the total energy requirement under potato crop production (54.7\%) due to high seed rate. Field operations required in the range of 14.1 to $30.5 \%$ of total energy required under different crops. Soybean, chickpea 
Table 1: Economic yields (tha ${ }^{-1}$ ) and system productivity $\left(\right.$ tha $^{-1}$ ) of different crops under nutrient supply options (mean of two years)

\begin{tabular}{llllllll}
\hline Treatment & Soybean & Wheat & Chickpea & Potato & Mungbean & $\begin{array}{l}\text { *Fodder } \\
\text { sorghum }\end{array}$ & $\begin{array}{l}\text { System } \\
\text { productivity }\end{array}$ \\
\hline $\begin{array}{l}\text { Cropping systems } \\
\text { Soybean-wheat }\end{array}$ & 1.68 & 4.74 & - & - & - & & \\
Soybean-wheat-mungbean & 1.70 & 4.79 & - & - & 0.55 & - & 4.89 \\
$\begin{array}{l}\text { Soybean-chickpea-fodder sorghum } \\
\text { Soybean-potato-mungbean }\end{array}$ & 1.69 & - & - & 22.51 & - & - & 5.46 \\
LSD (P=0.05) & 1.70 & - & 1.95 & - & 0.50 & 45.28 & 7.68 \\
Nutrient supply options & NS & NS & - & - & NS & - & 0.13 \\
Control & 1.49 & 3.48 & 1.67 & 12.63 & 0.45 & 32.95 & 4.75 \\
100\% RDF & 1.70 & 5.29 & 1.99 & 27.01 & 0.54 & 48.12 & 6.72 \\
$50 \%$ RDF + 50\% RDN-FYM & 1.72 & 5.16 & 2.15 & 26.08 & 0.59 & 51.42 & 6.79 \\
$50 \%$ RDF + 25\% RDN-FYM + biofertilizers & 1.75 & 5.06 & 1.90 & 22.88 & 0.50 & 46.11 & 6.40 \\
$25 \%$ RDF +50\% RDN-FYM + biofertilizers & 1.80 & 4.84 & 2.04 & 23.98 & 0.56 & 47.80 & 6.53 \\
LSD (P=0.05) & 0.14 & 0.31 & 0.23 & 2.57 & 0.04 & 4.50 & 0.28 \\
\hline
\end{tabular}

*Green fodder yield.

Table 2 : Energy requirement ( $\left.\times 103 \mathrm{MJ} \mathrm{ha}^{-1}\right)$ of crops under different inputs used and nutrient supply options (mean of two years)

\begin{tabular}{lllllll}
\hline Particulars & Soybean & Wheat & Chickpea & Potato & Mungbean & Fodder sorghum \\
\hline Field operations & $3.49(24.2)$ & $2.91(14.1)$ & $2.84(30.5)$ & $2.43(14.8)$ & $2.84(29.2)$ & $2.64(17.0)$ \\
Seed & $1.18(8.2)$ & $1.47(7.1)$ & $1.18(12.6)$ & $9.00(54.7)$ & $0.37(3.8)$ & $0.44(2.8)$ \\
Irrigation & $5.65(39.2)$ & $8.88(42.9)$ & $2.42(26.0)$ & $7.26(44.2)$ & $4.84(49.8)$ & $6.46(41.6)$ \\
Chemicals & $1.14(7.9)$ & $0.07(0.4)$ & $0.60(6.5)$ & $0.36(2.2)$ & $0.27(2.8)$ & $0.28(1.8)$ \\
Human labour & $0.46(3.2)$ & $0.40(1.9)$ & $0.34(3.6)$ & $0.65(4.0)$ & $0.23(2.3)$ & $0.25(1.6)$ \\
Nutrient supply options & & & & & \\
Control & - & - & & - & - \\
$100 \%$ RDF & $4.04(28.0)$ & $10.80(52.2)$ & $2.99(32.1)$ & $8.51(51.7)$ & $1.85(19.0)$ & $8.51(54.8)$ \\
$50 \%$ RDF + 50\% RDN-FYM & $3.34(23.2)$ & $9.58(46.3)$ & $2.66(28.6)$ & $7.47(45.4)$ & $1.60(16.5)$ & $7.47(48.1)$ \\
$50 \%$ RDF + 25\% RDN-FYM + biofertilizers & $2.70(18.7)$ & $7.49(36.2)$ & $2.10(22.5)$ & $5.90(35.9)$ & $1.28(13.2)$ & $5.87(37.9)$ \\
$25 \%$ RDF +50\% RDN-FYM + biofertilizers & $2.35(16.3)$ & $6.91(33.4)$ & $1.94(20.8)$ & $5.37(32.6)$ & $1.14(11.8)$ & $5.35(34.5)$ \\
Mean of nutrient supply & $2.49(17.3)$ & $6.96(33.6)$ & $1.94(20.8)$ & $5.45(33.1)$ & $1.18(12.1)$ & $5.44(35.1)$ \\
\hline
\end{tabular}

Figures in parentheses shows per cent of total energy used

and mungbean crops consumed lower energy input in fertilization (12.1 to $17.3 \%$ ), while wheat, potato and fodder sorghum crops required considerable amount of energy in fertilization (33.1 to $35.1 \%$ ) due to higher requirement of nutrients.

Soybean-potato-mungbean cropping system acquired highest energy input $\left(49.3 \times 10^{3} \mathrm{MJ} \mathrm{ha}^{-1}\right)$, followed by soybean-wheat-mungbean $\left(44.8 \times 10^{3} \mathrm{MJ} \mathrm{ha}^{-1}\right)$ and soybean-chickpea-fodder sorghum cropping system $\left(38.8 \times 10^{3}\right.$ MJ ha $^{-1}$ ) (Table 3).As wheat and potato require high irrigation and fertilizer this led to higher energy utilization by potato and wheat crops. Therefore, crop sequences having these crops increased the utilization of energy in the respective cropping systems. similar results were earlier reported by Mandal et al. (2002); Zangeneh et al. (2010) and Negi et al. (2016).

The nutrient supply treatments accounted for higher utilization of energy than unfertilized control (Table 3). Though the control treatment required lower energy input, but could not achieve potential yield of crops without nutrient supplementation (Table 1). Among the nutrient supply options, application of $100 \%$ RDF accounted for highest energy consumption (46.7 × $10^{3} \mathrm{MJ}$ $\left.\mathrm{ha}^{-1}\right)$. The substitution of part of RDF through organic manure and/or biofertilizers $\left(\mathrm{NM}_{2}\right.$ to $\left.\mathrm{NM}_{4}\right)$ resulted in reduced energy requirement for fertilization. The nutrient supply combination having $25 \%$ RDF along with 50\% RDN through FYM and biofertilizers required least energy input $\left(42.0 \times 10^{3} \mathrm{MJ} \mathrm{ha}^{-1}\right)$.

The calorific energy output was highest under soybean-chickpea-fodder sorghum cropping system (370.7 $\left.\times 10^{3} \mathrm{MJ} \mathrm{ha}^{-1}\right)$, followed by soybean-wheat-mungbean cropping system $\left(251.8 \times 10^{3} \mathrm{MJ} \mathrm{ha}^{-1}\right)$ (Table 3$)$. The wheat and sorghum crops in these systems showed high response to added fertilizers and irrigations, produced more biomass than potato and chickpea, consequently gave higher energy output from 


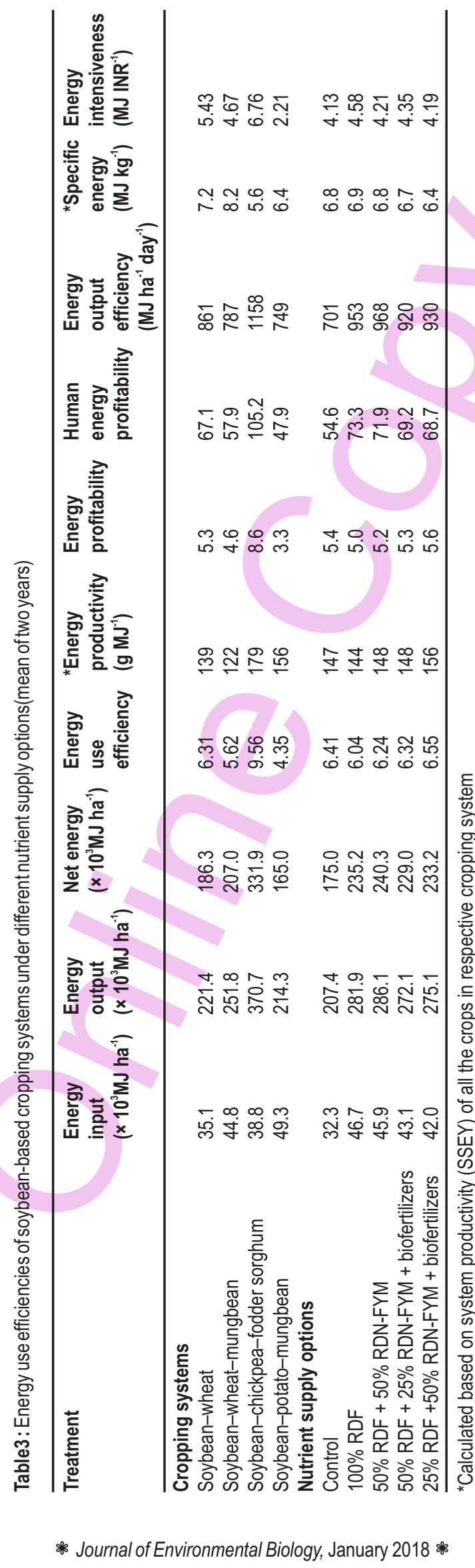


Table 4 : Mean carbon input/emission ( $\mathrm{kg} \mathrm{Ce} \mathrm{ha-}^{-1}$ ) under inputs used in different crops and nutrient supply options (mean of two years)

\begin{tabular}{lllllll}
\hline Particulars & Soybean & Wheat & Chickpea & Potato & Mungbean & Fodder sorghum \\
\hline Field preparations & $105.6(31.4)$ & $79.5(19.1)$ & $79.5(38.2)$ & $78.5(27.2)$ & $79.5(32.5)$ & $79.5(20.9)$ \\
Diesel & $18.8(5.6)$ & $23.5(5.6)$ & $18.8(9.0)$ & - & $18.8(7.7)$ & - \\
Fungicides & $10.3(3.1)$ & $2.5(0.6)$ & $8.4(4.0)$ & $6.4(2.2)$ & $10.3(4.2)$ & $2.5(0.7)$ \\
Insecticides & $19.7(5.9)$ & - & $7.4(3.6)$ & $4.9(1.7)$ & - & $74.0(19.5)$ \\
Herbicides & $16.6(5.0)$ & $3.0(0.7)$ & $9.6(4.6)$ & $4.9(1.7)$ & $9.6(.9)$ & $2.5(0.7)$ \\
Irrigation & $125.6(37.4)$ & $197.3(47.4)$ & $53.8(25.9)$ & $107.6(37.3)$ & $107.6(44.1)$ & $134.5(35.5)$ \\
Nutrient supply options & & & & & & - \\
Control & - & - & - & - & \\
100\% RDF & $58.4(17.4)$ & $153.7(36.9)$ & $42.6(20.4)$ & $122.4(42.4)$ & $26.4(10.8)$ & $122.4(32.3)$ \\
50\% RDF + 50\% RDN-FYM & $55.2(16.4)$ & $159.2(38.2)$ & $44.2(21.2)$ & $123.8(42.9)$ & $26.2(10.7)$ & $123.8(32.6)$ \\
50\% RDF + 25\% RDN-FYM + biofertilizers & $42.2(12.6)$ & $118.0(28.4)$ & $32.7(15.7)$ & $92.5(32.0)$ & $19.7(8.1)$ & $92.5(24.5)$ \\
25\% RDF +50\% RDN-FYM + biofertilizers & $40.7(12.1)$ & $120.8(29.0)$ & $33.6(16.1)$ & $93.1(32.3)$ & $19.6(8.0)$ & $93.1(24.5)$ \\
Mean of nutrient supply & $39.3(11.7)$ & $110.3(26.5)$ & $30.6(14.7)$ & $86.4(29.9)$ & $18.4(7.5)$ & $86.4(22.8)$ \\
\hline
\end{tabular}

Figures in parentheses shows per cent of total carbon input

Table 5 : Carbon input/emission equivalent, carbon output and carbon footprint of different soybean-based cropping systems under different nutrient supply options

\begin{tabular}{|c|c|c|c|c|}
\hline Treatment & $\begin{array}{l}\text { Carbon input } \\
\left(\mathrm{kg} \mathrm{C}_{\mathrm{e}} \mathrm{ha}^{-1}\right)\end{array}$ & $\begin{array}{l}\text { Carbon output } \\
\left(\mathrm{kg} \mathrm{C}_{\mathrm{e}} \mathrm{ha}^{-1}\right)\end{array}$ & Carbon efficiency & $\begin{array}{l}\text { Carbon foot print } \\
\left(\mathrm{kg} \mathrm{C}_{\mathrm{e}} \mathrm{kg}^{-1} \text { SSEY) }\right.\end{array}$ \\
\hline \multicolumn{5}{|l|}{ Cropping systems } \\
\hline Soybean-wheat & 752 & 5678 & 7.65 & 0.154 \\
\hline Soybean-wheat-mungbean & 996 & 7481 & 7.50 & 0.183 \\
\hline Soybean-chickpea-fodder sorghum & 924 & 9354 & 10.11 & 0.133 \\
\hline Soybean-potato-mungbean & 869 & 49 & 5.72 & 0.115 \\
\hline $\operatorname{LSD}(P=0.05)$ & - & 335 & 0.41 & 0.008 \\
\hline \multicolumn{5}{|l|}{ Nutrient supply options } \\
\hline Control & 731 & 5586 & 7.67 & 0.156 \\
\hline $100 \%$ RDF & 951 & 6357 & 6.48 & 0.146 \\
\hline $50 \%$ RDF + 50\% RDN-FYM & 952 & 7706 & 8.10 & 0.145 \\
\hline $50 \%$ RDF + 25\% RDN-FYM + biofertilizers & 896 & 7338 & 8.21 & 0.143 \\
\hline $25 \%$ RDF +50\% RDN-FYM + biofertilizers & 897 & 7400 & 8.27 & 0.141 \\
\hline $\operatorname{LSD}(P=0.05)$ & - & 635 & 0.67 & 0.013 \\
\hline
\end{tabular}

Table 6 : Net carbon flux in $20 \mathrm{~cm}$ soil profile of soybean-based cropping systems under different nutrient supply options

\begin{tabular}{|c|c|c|c|c|}
\hline Treatment & $\begin{array}{l}\text { Mean increase in } \\
\text { soil carbon } \\
\text { (g kg-1 soil) }\end{array}$ & 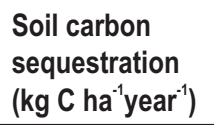 & $\begin{array}{l}\text { Carbon emission } \\
\left(\mathrm{kg} \mathrm{C}_{\mathrm{e}} \mathrm{ha}^{-1} \text { year }^{-1}\right)\end{array}$ & $\begin{array}{l}\text { Net flux } \\
\left(\text { kg C ha }^{-1} \text { year }^{-1}\right)^{*}\end{array}$ \\
\hline \multicolumn{5}{|l|}{ Cropping systems } \\
\hline Soybean-wheat & 0.34 & 750 & 752 & -2 \\
\hline Soybean-wheat-mungbean & 0.42 & 930 & 996 & -67 \\
\hline Soybean-chickpea-fodder sorghum & 0.41 & 907 & 924 & -16 \\
\hline Soybean-potato-mungbean & 0.38 & 851 & 869 & -18 \\
\hline \multicolumn{5}{|l|}{ Nutrient supply options } \\
\hline Control & 0.23 & 504 & 731 & -227 \\
\hline $100 \%$ RDF & 0.32 & 717 & 951 & -234 \\
\hline $50 \%$ RDF + 50\% RDN-FYM & 0.54 & 1210 & 952 & +258 \\
\hline $50 \%$ RDF + 25\% RDN-FYM + biofertilizers & 0.36 & 806 & 896 & -90 \\
\hline $25 \%$ RDF +50\% RDN-FYM + biofertilizers & 0.48 & 1075 & 897 & +179 \\
\hline
\end{tabular}

${ }^{*}$ Negative values indicate loss from the atmosphere and positive values indicate gain in the atmosphere 
respective cropping systems. The higher bio-energy output from wheat and maize crops due to production of higher biomass was also reported by Singh et al. (1997) and Jain et al. (2015). Owing to higher energy output, soybean-chickpea-fodder sorghum cropping system recorded highest net energy $\left(331.9 \times 10^{3} \mathrm{MJ}\right.$ $\left.\mathrm{h}^{-1}\right)$, energy efficiency (9.56), energy productivity $\left(179.0 \mathrm{gMJ}^{-1}\right)$, energy profitability (8.6), human energy profitability (105.2) and energy intensiveness (6.76) (Table 3). The per day energy output was also found highest in soybean-chickpea-fodder sorghum cropping system as it accounted for highest energy output efficiency of $1158 \mathrm{MJ} \mathrm{ha}^{-1}$ day ${ }^{-1}$. Soybean-wheat-mungbean cropping system had highest specific energy of $8.2 \mathrm{MJ} \mathrm{kg}^{-1}$ over other cropping systems. This indicates that this cropping system requires high energy input to produce a unit output. Despite the higher energy consumption, the soybean-chickpea-fodder sorghum system had the capacity to convert the input energy into higher biomass production and resulted in higher energy use efficiencies.

Among the nutrient supply options, integration of $50 \%$ RDF along with 50\% RDN through FYM resulted in highest total bio-energy production and net energy (Table 3 ). The higher energy output with integrated supply of nutrients due to increased biomass production was also reported by Billore et al. (2005). The lowest energy output was noted with the unfertilized treatment. The highest energy use efficiency, energy productivity and energy output efficiency were recorded with the application of $25 \% \mathrm{RDF}+$ $50 \%$ RDN through FYM and biofertilizers. The variable response was observed in other energy use indices under different nutrient supply options. The energy intensiveness was highest with $100 \%$ RDF as it accounted for lesser cost of nutrients when compared with FYM integrated treatment, while had the comparable energy output. The higher energy output and energy use efficiency recorded under nutrient sources combination having FYM and biofertilizers owing to higher productivity of most of the crops in the cropping systems. The results are in opinion with the results of Mandal et al. (2002) and Singh et al. (2015) who also observed higher energy output with combined use of nutrient sources.

Among the different inputs used for various practices, irrigation (25.9-47.4\%), tillage operations (field preparations and sowing) (19.1-38.2\%) and nutrient management (7.5-29.9\%) accounted for higher carbon input or emission equivalent across all the crops (Table 4).Crop intensification through inclusion of third crop in soybean-wheat cropping system led to increase in carbon input. Soybean-wheat-mungbeansystem increased $32.4 \%$ more carbon emission equivalent over soybean-wheat system (Table 5). Similarly, soybean-chickpea-fodder sorghum and soybean-potato-mungbean systems had 22.9 and $15.6 \%$ higher carbon emission equivalent over that of soybean-wheat system. The soybean-chickpea-fodder sorghum system recorded significantly highest carbon output equivalent $(9354 \mathrm{~kg}$ $\mathrm{C}_{\mathrm{e}} \mathrm{ha}^{-1}$ ) as well as carbon efficiency (10.11).The higher carbon input under soybean-wheat-mungbean cropping system also led to significantly highest carbon footprint. The lowest carbon footprint was observed under soybean-potato-mungbean (0.115 $\mathrm{kg} \mathrm{C}_{\mathrm{e}} \mathrm{kg}^{-1} \mathrm{SSEY}$ ), followed by soybean-chickpea-fodder sorghum system $\left(0.132 \mathrm{~kg} \mathrm{C}_{\mathrm{e}} \mathrm{kg}^{-1}\right.$ SSEY).

Among the nutrient supply options, the substitution of $50 \%$ RDN through FYM in the treatment 50\% RDF + 50\% RDN through FYM slightly increased the carbon input (Table 5). Singh et al. (2015) and Parmar et al. (2016) also observed an increase in carbon input with addition of organic manures. However, $25 \%$ RDF + 50\% RDN- FYM + biofertilizers and 50\% RDF + 25\% RDNFYM + biofertilizers treatment decreased the carbon input as compared to above treatment. The nutrient supplementation treatments resulted in significant increase in carbon output to the extent $>30 \%$ as compared to control treatment being highest where nutrient supply option comprised of $50 \%$ RDF $+50 \%$ RDNFYM. The carbon efficiency was significantly highest in the nutrient supply of $25 \%$ RDF $+50 \%$ RDN-FYM + biofertilizers followed by $50 \%$ RDF + 50\% RDN-FYM. The carbon footprint was significantly highest under unfertilized control treatment. This indicates that though it had lowest carbon emission equivalent but lower production of crop biomass resulted in low carbon output equivalent and higher carbon footprint. Other nutrient supply options maintained significantly lowest carbon footprint being lowest being at 25\% RDF + 50\% RDN-FYM + biofertilizers. Van Groenigen et al. (2010) also opined that optimization of nutrients supply through alternative source of nutrients with substantial reduction in chemical fertilizers can reduce the carbon footprint in crop production.

The estimation of net carbon flux provides the actual impact on the atmospheric $\mathrm{CO}_{2}$ concentration by using different agricultural practices. The carbon sequestration value alone pertains only to soil carbon stocks and is not representative of the effects of changes in agricultural practices on atmospheric $\mathrm{CO}_{2}$ (West and Marland, 2002). Net carbon flux indicates whether a system is a net contributor to atmospheric $\mathrm{CO}_{2}$ or reduces $\mathrm{CO}_{2}$. All the cropping system as well as nutrient supply combinations enhanced the carbon sequestration in the soil profile (Table 6). The soybean-wheat-mungbean system sequestered highest carbon in the soil followed by soybean-chickpea-fodder sorghum system. When carbon sequestered was compared with carbon emission under particular system, the net flux of carbon was negative in all the cropping systems. Despite of highest carbon sequestration, highest apparent loss in soil carbon was associated with soybean-wheat-mungbean ( $\left.67 \mathrm{~kg} \mathrm{C}^{-1} \mathrm{a}^{-1} \mathrm{year}^{-1}\right)$. This strives for an alternative technique like residue retention in soil and minimum tillage to decrease the rate of loss of soil organic carbon and increase carbon sequestration in soil profile (Lal etal., 1999).

Among the nutrient supply options, the combination of nutrient sources having 50\% RDN-FYM sequestered higher carbon in the soil profile and maintained positive values of carbon flux in the soil as compared to control and $100 \%$ RDF. This shows 
benefit of organic manure addition on balancing the carbon loss from the soil. Therefore, improved agricultural practices like integrated nutrient management can offset carbon emission from soils (West and Marland, 2002)

The study concludes that the soybean-chickpea-fodder sorghum cropping system maintained the highest net energy, energy efficiency and energy productivity. This system accounted for $51.5 \%$ higher energy efficiency than existing soybean-wheat system. The nutrient supply combination of $50 \%$ RDF $+50 \%$ RDN through FYM was efficient in terms of bio-energy production, net energy, carbon efficiency, as well as positive flux of soil carbon.

\section{Acknowledgments}

The first author sincerely acknowledges the Director, ICAR-Indian Agricultural Research Institute, New Delhi for providing financial assistance and facilities to conduct this study. The author also acknowledges the Indian Council of Agricultural Research for providing Senior Research Fellowship during the study.

\section{References}

Behera, U.K., A.R. Sharma and H.N.Pandey : Sustaining productivity of wheat-soybean cropping system through integrated nutrient management practices on the vertisols of Central India. Plant Soil, 297, 185-199 (2007).

Billore, S.D., A. Ramesh, O.P. Joshi and A.K.Vyas : Energy budgeting of soybean-based cropping system under various tillage and fertility management. Ind. J. Agric. Sci., 79, 827-830 (2009).

Billore, S.D., A.K. Vyas and O.P. Joshi : Effect of integrated nutrient management on productivity, energy use efficiency and economics of soybean-wheat cropping system. Ind. J. Agric. Sci., 75, 644-646 (2005).

Cavalaries, C.C. and T.A. Gemtos : Evaluation of tillage efficiency and energy requirements for five methods of soil preparation in the sugarbeet crop. In: Proceedings of Conference on Ecology Efficiency and Agricultural Engineering, Rousse, Bulgaria, pp. 110116 (2004).

Dubey, A. and R. Lal : Carbon footprint and sustainability of agriculture production systems in Punjab, India and Ohio, USA. J. Crop Improv., 23,332-350 (2009).

Franzluebbers, A.J. and C.A. Francis : Energy output, input ratio of maize and sorghum management systems in eastern Nebraska. Agric.Ecosys.Environ., 53, 271-278(1995).

Gan, Y., C. Liang, C. Hamel, H. Cutforth and H. Wang : Strategies for reducing the carbon footprint of field crops for semiarid areas:A review. Agron. Sust. Develop., 31, 643-656 (2011).

Gomez, K.A. and A.A. Gomez : Statistical Procedures for Agricultural Research. John Wiley and Sons, NewYork (1984).

Jain, N.K., Hari Singh, L.N. Dashora and S.L. Mundra : Diversification and intensification of maize (Zea mays)-wheat (Triticum aestivum) cropping system for sustainable productivity and profitability. Ind. J. Agron., 60, 38-44 (2015).

Khosa, M.K., B.S. Sidhu and D.K. Benhi : Effect of organic materials and rice cultivars on methane emission from rice field. J. Environ. Biol., 31, 281-285(2010).
Kumar, M., M.K. Jatav, S.P. Trehan and S.S. Lal : Integrated nutrient management in potato-based cropping systems for eastern IndoGangatic plains of India. Potato J., 36, 136-142 (2009).

Lal, R., R.F. Follett, J. Kimble and C.V. Cole : Managing US cropland to sequester carbon in soil. J. Soil Water Cons., 54, 374-381 (1999).

Lal, R.: Carbon emissions from farm operations. Environ. Int., 30,981990 (2004).

Malmuti, M., J.S. West, J. Watts, P. Gladders and B.D.L. Fitt : Controlling crop disease contributes to both food securityand climate change mitigation. Int. J. Agric. Sustain., 7,189-202 (2009).

Mandal, K.G., K.P. Sahab, P.K. Ghosh, K.M. Hati and K.K. Bandyopadhyaya : Bioenergy and economic analysis of soybeanbased crop production systems in central India. Biomass Bioenergy, 23, 337-345 (2002).

Negi, S.C., S.S. Rana, A. Kumar, S.K. Subehia and S.K. Sharma : Productivity and energy efficiency indices of diversified maize (Zea mays)-based cropping systems for mid hills of Himachal Pradesh. Indian J. Agron., 61, 9-14 (2016).

Oo, A.Z., K.T. Win, T. Motobayashi and S.D. Bellingrath-Kimura : Effect of cattle manure amendment and rice cultivars on methaneemission from paddy rice soil under continuously flooded conditions. J. Environ. Biol., 37, 1029-1036 (2016).

Parmar, D.K., D.R. Thakur, R.S. Jamwal and Arpana : Effect of long term organic manure application on soil properties,carbon sequestration, soil - plant carbon stock and productivity undertwo vegetable production systems in Himachal Pradesh. J. Environ. Biol., 37, 333-339 (2016).

Prajapat, K., A.K. Vyas and Shiva Dhar : Effect of cropping systems and nutrient management practices on growth, productivity, economics and nutrient uptake of soybean (Glycine max). Indian J. Agric. Sci., 85,1138-1143(2015).

Ramesh, P., N.R. Panwar, A.B. Singh and S. Ramana : Production potential, nutrient uptake, soil fertility and economics of soybean (Glycine max)-based cropping systems under organic, chemical and integrated nutrient management practices. Indian J.Agron., 54, 278-283 (2009).

Sharma, B.M. and R.V. Singh : STCR approach for fertilizer recommendations based on targeted yield concept. Technical Bulletin, Division of Soil Science and Agricultural Chemistry, Indian Agricultural Research Institute, New Delhi, p. 68 (2007).

Sharma, R.S. and C.L. Thakur : Economic and energy factors in soybean cultivation. Ind. J. Agron., 34, 337-340 (1989).

Singh, M.K., S.K. Pal, R. Thakur and U.N. Verma : Energy input-output relationship of cropping systems. Indian J. Agric. Sci., 67, 262-264 (1997).

Singh, R.J. and I.P.S. Ahlawat : Energy budgeting and carbon footprint of transgenic cotton-wheat production system through peanut inter cropping and FYM addition. Environ. Monit. Assess., 187, 1-16 (2015).

Singh, R.J., R.L. Meena, N.K. Sharma, S. Kumar, K. Kumar and D. Kumar : Economics, energy, and environmental assessment of diversified crop rotations in sub-Himalayas of India. Environ. Monit. Assess., 188, 1-13 (2016).

Singh, S. and J.P. Mittal : Energy in Production Agriculture. Mittal Publications, New Delhi, India (1992).

Smith, P., D. Martino, Z. Cai, D. Gwary, H. Janzen, P. Kumar, B. Mc Carl, S. Ogle, F. O'Mara, C. Rice, B. Scholes, O. Sirotenko, M. Howden, T. McAllister, G. Pan, V. Romanenkov, U. Schneider, S. Towprayoon, M. Wattenbach and J. Smith : Greenhouse gas 
mitigation in agriculture. Philos. Trans. R. Soc. Lond. B. Biol. Sci., 363,789-813 (2008).

Van Groenigen, J.W., G.L. Velthof, O. Oenema, K.J. Van Groenigen and

C. Van Kessel : Towards an agronomic assessment of $\mathrm{N}_{2} \mathrm{O}$ emissions: A case study for arable crops. Europ. J. Soil Sci., 61, 903-913(2010).

West, T.O. and G. Marland : A synthesis of carbon sequestration, carbon emissions and net carbon flux in agriculture: comparing tillage practices in the United States. Agric. Ecosys. Environ., 91, 217232 (2002).

Zangeneh, M., M. Omid and A. Akram : A comparative study on energy use and cost analysis of potato production under different farming technologies in Hamadan province of Iran. Energy, 35,2927-2933 (2010).

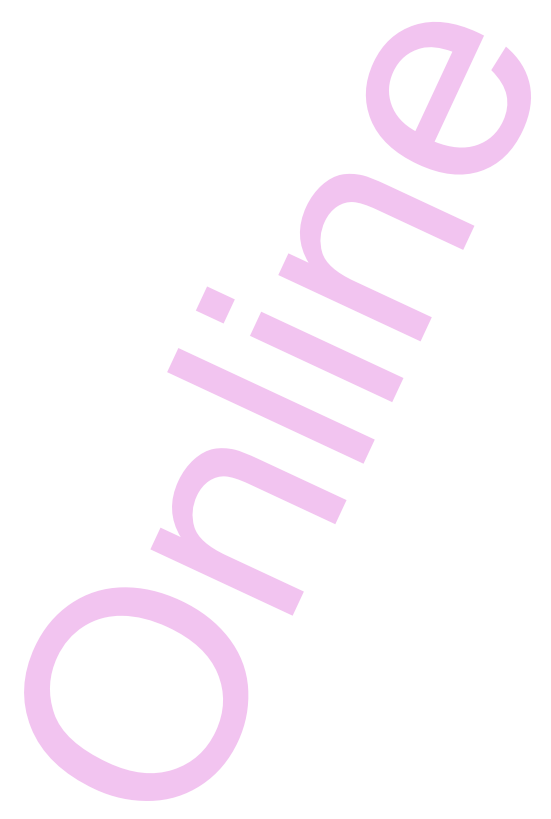

